\title{
Performance Assessment of Some Flax (Linum usitatissimum L.) Varieties Using Cluster Analysis under Sandy Soil Conditions
}

\author{
Bakry Ahmed Bakry*, Omar Maghawry Ibrahim, Tarek Abd El-Fattah Elewa, Mohamed \\ Farouk El-Karamany
}

Field Crops Research Department, National Research Centre, Dokki, Egypt

Email: Bakry ahmed2004@yahoo.com

Received 12 April 2014; revised 26 June 2014; accepted 12 July 2014

Copyright (C) 2014 by authors and Scientific Research Publishing Inc.

This work is licensed under the Creative Commons Attribution International License (CC BY).

http://creativecommons.org/licenses/by/4.0/

(c) (i) Open Access

\begin{abstract}
To assess the performance and the variability of 49 flax varieties based on agronomic parameters using cluster analysis, a field experiment was conducted in 2011/2012 and 2012/2013 winter seasons at the farm of the National Research Center at Nubria district, Albehira Governorate, Egypt. The results revealed high significant difference among all flax varieties in all the studied characters. Letwania-9 and Evelen cultivars surpassed all other varieties in seed and oil yiel$\mathrm{ds} /$ fed. On the other hand, $D$ variety gave the lowest value of seed yield/fed and $F$ variety gave the lowest values of oil\% and oil yield/fed. While, G Variety surpassed all other varieties in straw yield/fed. Blanka variety recorded the lowest values of straw yield/fed and biological yield/fed, while, Posna variety gave the lowest values of technical stem length $(\mathrm{cm})$. In cluster analysis, all the studied characters were used to construct a distance matrix using the Euclidian coefficient, and generate dendrogram showing dissimilarity among all the varieties. Distance coefficient was ranged from 1.2 between Piltstar and Litwania-1 varieties and 10.8 between Posna and G varieties, which reveal the genetic diversity among varieties. The varieties can be divided into 4 groups based on cluster analysis.
\end{abstract}

Keywords

Flax, Linum usitatissimum, Diversity, Dissimilarity, Agronomic Characters, Cluster Analysis

\section{Introduction}

Flax (Linum usitatissimum L.) is a dual source of products; seeds for oil and straw for linen products. The oil is "Corresponding author.

How to cite this paper: Bakry, A.B., Ibrahim, O.M., Abd El-Fattah Elewa, T. and El-Karamany, M.F. (2014) Performance Assessment of Some Flax (Linum usitatissimum L.) Varieties Using Cluster Analysis under Sandy Soil Conditions. Agricultural Sciences, 5, 677-686. http://dx.doi.org/10.4236/as.2014.58071 
edible and also is used for the preparation of paints, varnishes, printing ink, due to its quick drying property. The fiber is soft and flexible. It is, however, stronger than cotton or wool. The best grades of flax fiber are used for linen fabrics, the coarser grades for twines, canvas and bags. Raw flax fiber is also used to make high quality paper and components for the motor industry. Linseed designates the varieties used for oil, human food and livestock feed. Flax requires abundant moisture and cool weather during the growing season [1]. According to [2] cool temperatures combined with a long photoperiod during and after flowering increases seed yield. The cultivated area through the last 20 years was decreased from 60,000 to 30,000 feddan due to the great competition of other economic winter crops resulting in a gap between production and consumption. Therefore, it is necessary to increase flax productivity per unit area which could be achieved by using high yielding cultivars and improving the agricultural treatments [3] and [4]. In Egypt, flax plays an important role in the national economy via export and local industry. Increasing the production of flax from the current limited areas is considered as a basic target. This could be achieved through growing high yielding varieties and proper planting dates occupy an important role in this respect. Many investigators obtained varietal differences in yield and quality of flax in many regions of growing flax [5]-[9]. Many investigators reported significant differences among flax varieties concerning seed, straw, oil and fiber yields as well as their components, [10] and [11]. Due to the global climatic changes some agronomic practices of the crops have been changed.

The use of cluster analysis algorithms is an important strategy for classifying, ordering variability for a large number of varieties, or analyzing genetic relationships among materials. This statistical analysis has several advantages [12]. First, it allows mixing of both qualitative and quantitative data and therefore all the available information on the sample can be utilized. Cluster analysis had been used in widely different fields [13]. It can be used as a tool of selection and data reduction via similarity coefficient, similar varieties might be considered as one group in the second test of performance provided that they have genetic diversity among them to avoid inbreeding effect. Also, it provides useful information about genetic diversity in crops. The cluster analysis was used to see whether the varieties fell into groups or clusters.

The present investigation was carried out to assess the performance of 49 flax varieties under sandy soils conditions.

\section{Materials and Methods}

Two field experiments were conducted at the farm of the National Research Center at Nubria district AlBehira Governorate, Egypt in 2011/2012 and 2012/2013 winter seasons to assess the performance and the variability of 49 flax varieties, based on agronomic parameters using cluster analysis. The experimental soil was analyzed according to the method described by [14]. Soil texture was sandy and having the following characteristics:

Sand 93.7\%; pH 7.8; organic matter 0.65\%; $\mathrm{CaCO}_{3} 1.30 \%$; EC $0.50 \mathrm{dS} / \mathrm{m}$; total N 8.1 ppm, P $3.60 \mathrm{ppm}$ and K $23.5 \mathrm{ppm}$. To assess the performance and the variability of 49 flax varieties based on agronomic parameters using cluster analysis, varieties were arranged in randomized complete block design with four replicates where the plot area was $10.5 \mathrm{~m}^{2}$ (One fed $=4200 \mathrm{~m}^{2}$ ) Flax seeds were sown in mid November in both seasons. Irrigation was carried out using sprinkler irrigation system where water was added every 5 days. Only calcium super phosphate $\left(15.5 \% \mathrm{P}_{2} \mathrm{O}_{5}\right)$ and potassium fertilizer $48 \%$ as $\mathrm{K}_{2} \mathrm{O}$ were added during seed bed preparation at the level of 31.00 and 24.00 (kg/fed), respectively, while nitrogen fertilizer as ammonium nitrate (33.5\%) was added at the rate of (75 kg N/fed). Flax plants were pulled at full maturity, and then left on ground for air-drying. Capsules were removed carefully. At harvest the following characters were recorded on a random sample of ten guarded plants from each plot.

\subsection{Straw Yield and Its Components}

Plant height (cm), technical stem length (cm), straw yield (g/plant), straw yield (tons/fed) and biological yield (tons/fed).

\subsection{Seed Yield and Its Related Characters}

Number of fruiting branches/plant, number of capsules/plant, fruiting zone length $(\mathrm{cm})$, seed yield (g/plant), seed yield (kg/fed), seed oil\% was determined by soxhlet apparatus using petroleum ether $\left(40^{\circ} \mathrm{C}-60^{\circ} \mathrm{C} \mathrm{b.p)}\right.$ according to the method [15]. Oil yield (kg/fed) was calculated by seed yield (kg/fed) * seed oil (\%).

The obtained results were subjected to statistical analysis of variance according to method described by [16], 
since the trend was similar in both seasons the homogeneity test Bartlet's equation was applied and the combined analysis of the two seasons was calculated according to the method [17].

The cluster analysis was performed using the program SAS v.9.1.3 that adopts Euclidian distance as a measure of dissimilarity and the Ward's method as the clustering algorithm [18]. Before computing the distance between varieties, our data were standardized as recommended by [19]. Euclidean Distance is the square root of the sum of squared differences between two variables and its equation is as follows:

$$
d(x, y)=\sqrt{\sum_{i}^{n}\left(x_{i}-y_{i}\right)^{2}}
$$

\subsection{Origins of Flax Varieties}

- Litwania-1, Litwania-2, Litwania-3, Litwania-4, Litwania-5, Litwania-6, Litwania-7 and Litwania-9 (Litwania origin varieties).

- $\quad$ Line-1, Line-3, Line-4, Line-6, Line-7, Line-8, Line-9, Line-10, Line-11, Line-12, Line-13 and Olin (Romania origin varieties).

- B, C, D, E, F, G, H, I, K and V (China origin varieties).

- Giza-5, Giza-6, Giza-8, Sakha-1 and Sakha-2 (Egypt origin varieties).

- Piltstar, Vaiking, Blanka, Vaiko, Mayic, Texa, Artimedia, Evelen and Alba (France origin varieties).

- Agretic and Amon (Czech Republic origin varieties).

- Opal and Szafir (Polanda origin varieties).

\section{Results and Discussions}

\subsection{Seed, Oil Yields and Its Related Characters}

Data presented in Table 1 revealed that high significant difference among all flax varieties in seed and oil yields and its related characters. Letwania-9 and Evelen cultivars surpassed all other varieties in seed and oil yields/fed. and there were no significant differences between Letwania-9 and Evelen cultivars in seed yield/fed. The superiority in seed yield/fed for both varieties may be due to the increases in fruiting zone length and the number of fruiting branches/plant. Moreover, the superiority in oil yield/fed may be attributed to the increase in seed yield /fed and the increase in seed oil\%. Such results are in agreement with these obtained by many investigators, [7] [8] [20] [21]. However, there were no significant differences between Letwania-2, Letwania-7, Letwania-9 and Line-8 varieties but significantly exceeded between all the other varieties in fruiting zone length. Such results are in agreement with those obtained by [10] [11] [21] [22]. Whereas, Posna and Olin significantly exceeded all the other varieties in number of capsules/plant.

Regarding minimum values of seed and oil yields and its related characters under this investigation, the same table showed that Szafir variety gave the lowest values of plant height $(57.33 \mathrm{~cm})$ and fruiting zone length $(10 \mathrm{~cm})$, Lin-9 variety gave the lowest values of number of capsules/ plant (5.67) and biological yield/plant (1.00 g), D variety gave the lowest value of seed yield/fed $(192.15 \mathrm{~kg})$ and $\mathrm{F}$ variety gave the lowest values of oil \% and oil yield/fed, These results indicated that the variability among all tested flax varieties which may be expected due to the differences of these varieties in origin, growth habit, genetic constituent and the environmental conditions of investigated cultivars under newly reclaimed sandy soil of Nubaria district. Such results are in agreement with these obtained by many investigators such as [7] [21] [22].

\subsection{Straw Yield and Its Related Characters}

Data presented in Table 1 indicated that high significant difference among all flax varieties in straw yield and its related characters. G Variety surpassed all other varieties in straw yield/fed and there were no significant differences between G, E and H Varieties in straw yield/fed. This superiority in straw yield /fed for this varieties may be due to the increases in plant height, technical stem length and biological yield/fed. The differences between the tested flax varieties could mainly be attributed to the differences in their genetical constitution and their response to the environmental conditions. In this connections, many investigators obtained higher levels of varietal differences in straw yield and its components in many regions of growing flax in the world, [20] [23]-[27]. 
Table 1. Analysis of variance of agronomic characters of 49 flax varieties (combined analysis).

\begin{tabular}{|c|c|c|c|c|c|c|c|c|c|c|c|c|c|}
\hline Varieties & $\mathrm{X} 1$ & $\mathrm{X} 2$ & X3 & $\mathrm{X} 4$ & X5 & X6 & X7 & X8 & X9 & $\mathrm{X} 10$ & X11 & $\mathrm{X} 12$ & $\mathrm{X} 13$ \\
\hline Litwania-9 & 75.33 & 52.00 & 23.33 & 4.67 & 9.67 & 0.81 & 1.20 & 882.00 & 3.05 & 2.01 & 36.35 & 320.61 & 3.93 \\
\hline Evelen & 69.33 & 50.67 & 18.67 & 4.67 & 13.33 & 0.76 & 1.80 & 866.25 & 2.77 & 2.56 & 35.66 & 308.90 & 3.64 \\
\hline Alba & 83.33 & 60.33 & 23.00 & 4.00 & 14.00 & 0.54 & 2.10 & 771.75 & 2.57 & 2.64 & 38.47 & 296.89 & 3.34 \\
\hline Line-9 & 70.00 & 57.33 & 12.67 & 3.33 & 5.67 & 0.50 & 0.50 & 689.85 & 3.68 & 1.00 & 36.97 & 255.04 & 4.37 \\
\hline G & 91.67 & 76.67 & 15.00 & 4.00 & 6.33 & 1.74 & 0.40 & 683.55 & 4.72 & 2.14 & 39.38 & 269.18 & 5.40 \\
\hline Line-1 & 70.67 & 56.67 & 14.00 & 5.00 & 11.00 & 1.00 & 1.60 & 680.40 & 3.14 & 2.60 & 35.87 & 244.06 & 3.82 \\
\hline Litwania-3 & 70.33 & 54.67 & 15.67 & 4.00 & 9.00 & 0.68 & 1.10 & 630.00 & 2.75 & 1.78 & 37.13 & 233.92 & 3.38 \\
\hline Litwania-7 & 80.67 & 57.67 & 23.00 & 4.33 & 18.00 & 2.41 & 1.20 & 626.85 & 1.79 & 3.61 & 32.94 & 206.48 & 2.42 \\
\hline Line-12 & 80.00 & 61.67 & 18.33 & 4.67 & 10.00 & 1.05 & 1.20 & 607.95 & 3.03 & 2.25 & 39.22 & 238.44 & 3.64 \\
\hline Sahka-2 & 77.00 & 63.33 & 13.67 & 5.33 & 10.33 & 0.40 & 1.50 & 567.00 & 2.81 & 1.90 & 37.17 & 210.75 & 3.38 \\
\hline C & 87.67 & 67.00 & 20.67 & 4.67 & 13.33 & 2.05 & 1.70 & 519.75 & 3.55 & 3.75 & 42.10 & 218.81 & 4.07 \\
\hline Giza-5 & 69.67 & 54.33 & 15.33 & 3.00 & 8.67 & 0.65 & 1.40 & 510.30 & 2.02 & 2.05 & 35.90 & 183.20 & 2.53 \\
\hline Giza-6 & 71.67 & 56.00 & 15.67 & 4.33 & 14.33 & 1.61 & 1.30 & 504.00 & 2.71 & 2.91 & 35.90 & 180.94 & 3.21 \\
\hline Amon & 62.00 & 44.67 & 17.33 & 4.33 & 12.00 & 1.37 & 1.10 & 478.80 & 2.31 & 2.47 & 38.24 & 183.09 & 2.79 \\
\hline E & 105.67 & 86.33 & 19.33 & 4.33 & 11.33 & 4.25 & 0.70 & 472.50 & 4.59 & 4.95 & 36.72 & 173.50 & 5.09 \\
\hline K & 90.00 & 68.67 & 21.33 & 4.67 & 12.00 & 3.41 & 0.50 & 467.90 & 1.41 & 3.91 & 34.09 & 159.51 & 1.88 \\
\hline Mayic & 77.33 & 60.67 & 16.67 & 4.67 & 11.67 & 1.22 & 1.80 & 463.05 & 2.54 & 3.02 & 38.24 & 177.07 & 3.00 \\
\hline Opal & 62.67 & 44.67 & 18.00 & 3.33 & 13.00 & 0.83 & 1.40 & 459.90 & 1.78 & 2.23 & 41.76 & 192.05 & 2.24 \\
\hline Line-3 & 83.33 & 68.00 & 15.33 & 5.33 & 14.33 & 1.28 & 2.10 & 453.60 & 1.97 & 3.38 & 37.04 & 168.01 & 2.42 \\
\hline Sahka-1 & 79.67 & 65.00 & 14.67 & 3.67 & 8.67 & 0.60 & 1.40 & 447.30 & 3.31 & 2.00 & 36.40 & 162.82 & 3.76 \\
\hline Vaiko & 65.00 & 48.67 & 16.33 & 4.33 & 15.00 & 1.82 & 2.10 & 437.85 & 2.44 & 3.92 & 45.11 & 197.51 & 2.88 \\
\hline Line-13 & 89.67 & 68.00 & 21.67 & 4.67 & 18.00 & 2.37 & 2.40 & 431.55 & 1.41 & 4.77 & 38.27 & 165.15 & 1.84 \\
\hline Line-11 & 67.00 & 54.00 & 13.00 & 3.33 & 6.67 & 0.49 & 0.70 & 412.65 & 3.00 & 1.19 & 36.62 & 151.11 & 3.41 \\
\hline Line-7 & 70.33 & 55.33 & 15.00 & 4.33 & 12.67 & 1.95 & 0.50 & 409.50 & 2.84 & 2.45 & 36.07 & 147.71 & 3.25 \\
\hline Litwania-6 & 79.67 & 59.67 & 20.00 & 4.67 & 14.67 & 1.19 & 1.50 & 409.50 & 2.91 & 2.69 & 36.77 & 150.57 & 3.32 \\
\hline $\mathrm{V}$ & 79.33 & 57.00 & 22.33 & 3.00 & 10.33 & 0.48 & 1.90 & 409.50 & 2.77 & 2.38 & 37.82 & 154.87 & 3.18 \\
\hline Line-4 & 72.33 & 60.67 & 11.67 & 4.00 & 8.33 & 0.71 & 1.00 & 396.90 & 2.71 & 1.71 & 39.48 & 156.70 & 3.11 \\
\hline Line-8 & 83.00 & 59.33 & 23.67 & 4.33 & 16.33 & 2.45 & 2.60 & 393.75 & 2.42 & 5.05 & 38.76 & 152.62 & 2.81 \\
\hline Line-10 & 80.00 & 67.67 & 12.33 & 4.00 & 6.67 & 0.75 & 0.90 & 378.00 & 3.05 & 1.65 & 38.00 & 143.64 & 3.43 \\
\hline B & 100.33 & 81.33 & 19.00 & 3.67 & 11.00 & 2.67 & 1.20 & 378.00 & 3.11 & 3.87 & 35.01 & 132.34 & 3.49 \\
\hline Posna & 63.33 & 41.33 & 22.00 & 4.67 & 23.67 & 2.13 & 2.20 & 365.40 & 1.37 & 4.33 & 40.79 & 149.05 & 1.74 \\
\hline Giza-8 & 67.67 & 53.00 & 14.67 & 4.33 & 12.33 & 0.77 & 1.50 & 352.80 & 1.69 & 2.27 & 38.11 & 134.45 & 2.04 \\
\hline Artimedia & 67.33 & 55.00 & 12.33 & 3.67 & 9.00 & 0.97 & 0.70 & 346.50 & 2.02 & 1.67 & 36.86 & 127.72 & 2.37 \\
\hline Szafir & 57.33 & 47.33 & 10.00 & 4.00 & 10.67 & 0.82 & 1.60 & 315.00 & 1.46 & 2.42 & 39.05 & 123.01 & 1.78 \\
\hline Olin & 60.33 & 42.33 & 18.00 & 5.33 & 22.33 & 1.96 & 2.00 & 315.00 & 2.09 & 3.96 & 38.05 & 119.86 & 2.41 \\
\hline
\end{tabular}




\begin{tabular}{|c|c|c|c|c|c|c|c|c|c|c|c|c|c|}
\hline \multicolumn{14}{|l|}{ Continued } \\
\hline Texa & 72.67 & 57.33 & 15.33 & 4.33 & 13.00 & 2.49 & 0.20 & 311.85 & 2.08 & 2.69 & 37.10 & 115.70 & 2.39 \\
\hline Line-6 & 68.67 & 55.00 & 13.67 & 4.67 & 13.33 & 0.64 & 1.90 & 302.40 & 2.50 & 2.54 & 42.01 & 127.04 & 2.80 \\
\hline Litwania-1 & 68.67 & 53.67 & 15.00 & 4.00 & 10.00 & 1.12 & 0.60 & 299.25 & 1.74 & 1.72 & 37.77 & 113.03 & 2.04 \\
\hline Piltstar & 65.33 & 50.33 & 15.00 & 3.67 & 9.67 & 1.22 & 1.00 & 292.95 & 2.04 & 2.22 & 38.66 & 113.25 & 2.33 \\
\hline Vaiking & 69.33 & 47.67 & 21.67 & 3.33 & 9.33 & 0.69 & 1.10 & 286.65 & 1.73 & 1.79 & 37.83 & 108.44 & 2.02 \\
\hline Blanka & 66.67 & 46.67 & 20.00 & 3.67 & 9.67 & 0.94 & 1.70 & 277.20 & 1.19 & 2.64 & 36.12 & 100.12 & 1.47 \\
\hline Litwania-5 & 90.33 & 71.33 & 19.00 & 5.00 & 19.33 & 3.29 & 0.60 & 274.05 & 3.02 & 3.89 & 38.61 & 105.81 & 3.29 \\
\hline Litwania-4 & 84.00 & 66.00 & 18.00 & 4.00 & 13.67 & 1.51 & 0.70 & 274.05 & 3.02 & 2.21 & 38.61 & 105.81 & 3.29 \\
\hline $\mathrm{H}$ & 99.33 & 83.33 & 16.00 & 4.67 & 9.00 & 2.55 & 0.50 & 274.05 & 4.79 & 3.05 & 37.46 & 102.66 & 5.06 \\
\hline I & 90.33 & 73.33 & 17.00 & 3.67 & 10.00 & 2.54 & 0.70 & 267.75 & 2.79 & 3.24 & 37.52 & 100.46 & 3.06 \\
\hline Agretic & 61.67 & 45.33 & 16.33 & 4.33 & 11.67 & 0.38 & 0.70 & 267.75 & 1.95 & 1.08 & 36.84 & 98.64 & 2.22 \\
\hline Litwania-2 & 84.67 & 60.67 & 24.00 & 4.67 & 17.33 & 1.98 & 1.50 & 267.75 & 1.91 & 3.48 & 37.57 & 100.59 & 2.18 \\
\hline F & 85.00 & 71.67 & 13.33 & 4.33 & 7.33 & 1.25 & 0.30 & 252.00 & 3.99 & 1.55 & 29.36 & 73.99 & 4.24 \\
\hline $\mathrm{D}$ & 93.00 & 76.00 & 17.00 & 4.33 & 7.33 & 1.84 & 0.70 & 192.15 & 2.85 & 2.54 & 39.86 & 76.59 & 3.04 \\
\hline LSD (0.05) & 15.39 & 11.98 & 3.41 & 0.85 & 2.39 & 0.29 & 0.25 & 87.24 & 0.53 & 0.54 & 7.53 & 3.28 & 0.62 \\
\hline
\end{tabular}

$\mathrm{X} 1$ = plant height $(\mathrm{cm}), \mathrm{X} 2=$ technical length $(\mathrm{cm}), \mathrm{X} 3=$ fruiting zone length $(\mathrm{cm}), \mathrm{X} 4=$ number of branches, X5=number of capsules, X6 = Straw yield (g/plant), X7 = seed yield (g/plant), X8 = seed yield (kg/fed), X9 = straw yield (ton/fed), X10 = biological yield (g/plant), X11 = oil\%, X12 = oil yield $(\mathrm{kg} / \mathrm{fed}), \mathrm{X} 13$ = biological yield $(\mathrm{ton} / \mathrm{fed})$.

Regarding minimum values of straw yield and its related characters, the same table indicated that Blanka variety recorded the lowest values of straw yield (1.19 ton/fed) and biological yield (1.47 ton/fed) while, Posna variety gave the lowest values of technical stem length $(41.33 \mathrm{~cm})$. These results indicated that the high variability among all tested flax genotypes due to the differences of these varieties in origin, growth habit, genetic constituent and the environmental conditions of investigated cultivars under newly reclaimed sandy soil of Nubaria district. Such results are in agreement with these obtained by many investigators such as [21] and [22].

\subsection{Cluster Analysis}

Cluster analysis was approved as a suitable method for data classifying and suggested by [28]. The average of all the studied characters of the two seasons in (Table 1) was used to construct a distance matrix using the Euclidian coefficient (Table 2) and the data from the distance matrix was used to generate the dendrogram showing dissimilarity among all the varieties [19] Figure 1. Posna and G varieties were the most dissimilar to each other with distance coefficient of 10.8. On contrast, Litwania-1 and Piltstar varieties were the most similar varieties with dissimilarity coefficient of 1.23 this may suggest that these varieties could be originated from a single source.

Based on the cluster analysis in Figure 1, we can divide the 49 varieties into 4 groups based on the studied agronomic characters as shown in Table 3 and Table 4 which reveal that the first group was the highest in seed yield/fed (average $715.05 \mathrm{~kg} / \mathrm{fed}$ ) and oil yield/fed (average $26.48 \mathrm{~kg} / \mathrm{fed}$ ), this means that this group is suitable for the production of seeds. On the other hand, the fourth group was the lowest in seed yield/fed (average 364.89 $\mathrm{kg} / \mathrm{fed}$ ), however, it was the highest in straw yield/fed (3.7 ton/fed), and consequently it is a suitable group for producing fiber.

The second and third groups had intermediate values of seed and straw yield and hence are suitable for a dual purpose of producing seed and fiber.

\section{Conclusion}

The results of this study introduce information about the diversity among 49 flax varieties which we should give attention to. They are of particular interest for the further collecting of genetic resources and show a wide spec- 
A. B. Bakry et al.

Table 2. Distance matrix based on Euclidian coefficient for the 49 flax varieties. Using data from the two seasons.

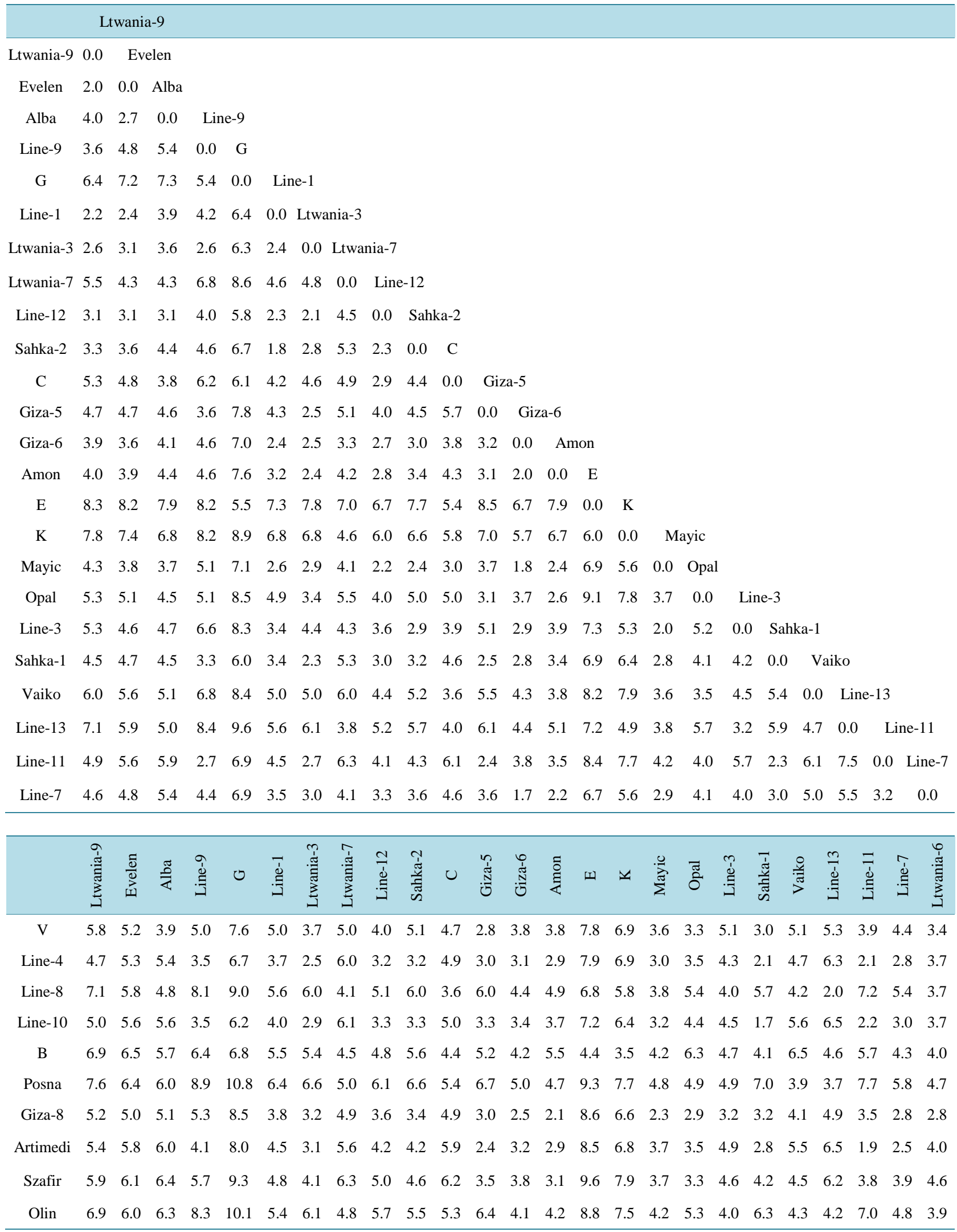




\section{Continued}

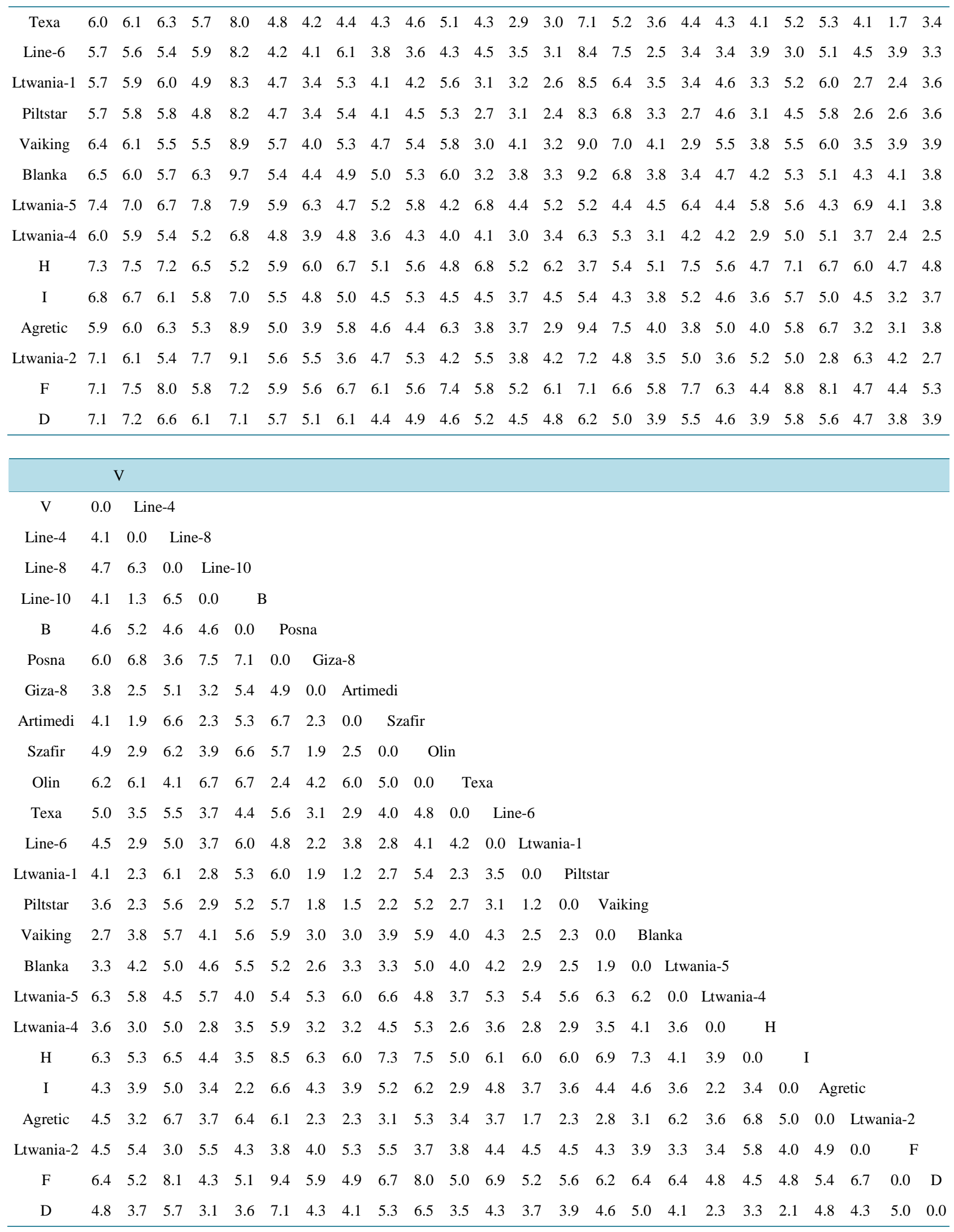




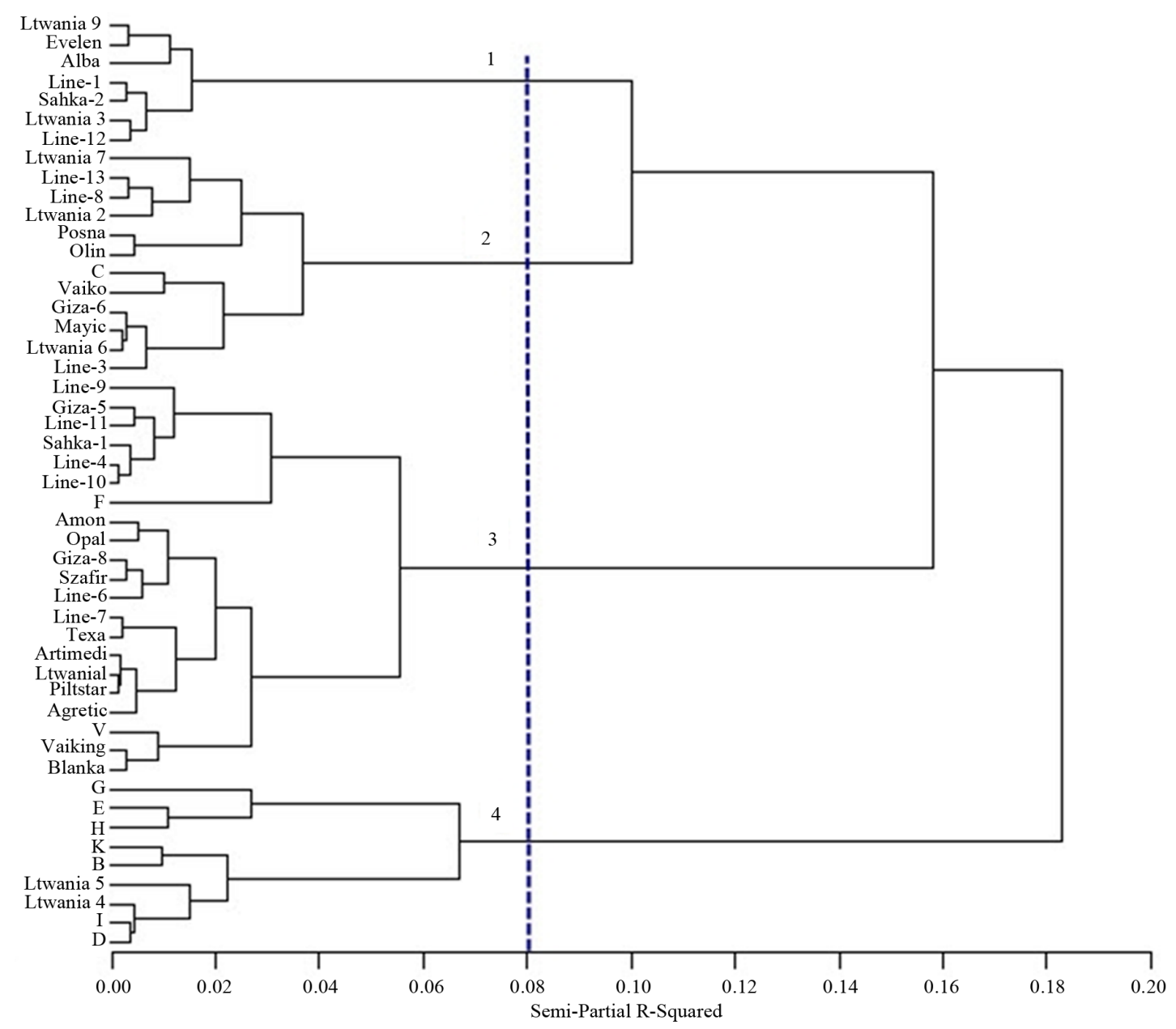

Figure 1. Dendrogram showing cluster analysis (Ward method) of 49 flax varieties.

Table 3. Agronomic characters mean values of flax varieties groups issued from cluster analysis.

\begin{tabular}{cccccccccccccc}
\hline & X1 & X2 & X3 & X4 & X5 & X6 & X7 & X8 & X9 & X10 & X11 & X12 & X13 \\
\hline Group1 & 73.86 & 57.05 & 16.81 & 4.62 & 11.05 & 0.75 & 1.50 & 715.05 & 2.87 & 2.25 & 37.12 & 26.48 & 3.59 \\
Group2 & 77.20 & 57.45 & 19.75 & 4.67 & 16.58 & 1.87 & 1.87 & 432.34 & 2.26 & 3.74 & 38.46 & 16.56 & 2.69 \\
Group3 & 69.68 & 54.46 & 15.22 & 3.84 & 9.94 & 0.93 & 1.05 & 376.05 & 2.37 & 1.99 & 37.47 & 14.12 & 2.75 \\
Group4 & 96.07 & 78.11 & 17.96 & 4.26 & 11.11 & 2.64 & 0.67 & 364.89 & 3.70 & 3.31 & 37.47 & 13.62 & 4.06 \\
\hline
\end{tabular}

$\mathrm{X} 1=$ plant height $(\mathrm{cm}), \mathrm{X} 2=$ technical length $(\mathrm{cm}), \mathrm{X} 3=$ fruiting zone length $(\mathrm{cm}), \mathrm{X} 4=$ number of branches, $\mathrm{X} 5=$ number of capsules, $\mathrm{X} 6=$ Straw yield $(\mathrm{g} / \mathrm{plant}), \mathrm{X} 7 \mathrm{=}$ seed yield $(\mathrm{g} / \mathrm{plant}), \mathrm{X} 8=$ seed yield $(\mathrm{kg} / \mathrm{fed}), \mathrm{X} 9=$ straw yield $(\mathrm{ton} / \mathrm{fed}), \mathrm{X} 10=$ biological yield (g/plant), X11 = oil\%, X12 = oil yield (kg/fed), X13 = biological yield (ton/fed).

Table 4. Flax varieties groups issued from cluster analysis.

\begin{tabular}{|c|c|c|c|c|c|c|c|c|c|c|c|c|c|}
\hline Group 1 & Seed & Litwania-9 & Evelen & Line-1 & Litwania-3 & Sahka-2 & Alba & Line-12 & - & - & - & - & - \\
\hline Group 2 & Dual & Litwania-7 & Olin & Giza-6 & Mayic & Litwania-2 & Line-3 & Vaiko & Line-13 & Litwania-6 & Line-8 & Posna & $\mathrm{C}$ \\
\hline Group 3 & Dual & Line-7 & Texa & Artimedia & Piltstar & Litwania-1 & Agretic & $\mathrm{V}$ & Vaiking & Blanka & Line-6 & - & - \\
\hline Group 4 & Fiber & $\mathrm{E}$ & G & $\mathrm{H}$ & $\mathrm{K}$ & B & Litwania-5 & Litwania-4 & $\mathrm{I}$ & $\mathrm{D}$ & - & - & - \\
\hline
\end{tabular}


trum of agronomic variability among the varieties investigated. The results obtained have shown that the agronomic parameters are very useful for the initial description. The cluster analysis with the agronomic data of flax revealed the existence of variations among varieties.

\section{References}

[1] Berger, J. (1969) In the World’s Major Fiber Crops their Cultivation and Manuring. Part 1, Flax, 209-213.

[2] O’connor, B.J. and Gusta, L.V. (1993) Effect of Low Temperature and Seeding Depth on the Germination and Emergence of Seven Flax (Linum usitatissimum L.) Cultivars. Canadian Journal of Plant Science, 74, 247-253. http://dx.doi.org/10.4141/cjps94-050

[3] Hussein, M.M.M. (2007) Response of Some Flax Varieties to Bio and Nitrogen Fertilization. Zagazig Journal of Agricultural Research, 34, 815-844.

[4] Ibrahim, H.M. (2009) Effect of Sowing Date and N-Fertilizer Levels on Seed Yield, Some Yield Components and Oil Content in Flax. Alexandria Journal of Agricultural Research, 54, 19-28.

[5] El-Shimy, G.M., Mostafa, S.H.A. and Zedan, S.Z. (1997) Studies on Yield, Yield Components, Quality and Variability in Some Flax Varieties. Egyptian Journal of Agricultural Research, 75, 697-715.

[6] Kineber, M.E.A. and El-Kady, E.A.F. (1996) Response of Some Promising Flax Varieties to Soil Salinity. Proceedings of 7th Conference Agronomy, Mansoura, 2, 369-378.

[7] El-Sweify, A.H.H., Tag El-Din, M.A. and Sharaf El-Deen, H.A.M. (2003) Effect of Some Flax Varieties and Harvesting Dates on Seed Chemical Composition, Yield and Fiber Quality. Annals of Agricultural Science, 41, 19-37.

[8] Abd El-Fatah, A.A.E. (2007) Comparative Study on Some Flax Cultivars. Journal of Agricultural Science, 32, 71117119.

[9] El-Kady, E.A.F. and Abd El-Fatah, A.A.E. (2009) Comparison of Yield, Its Components, Physical Properties and Chemical Composition of Twelve Flax Varieties. Journal of Agricultural Research, 35, 69-85.

[10] El-Hariri, D.M., Hassanein, M.S. and Ahmed, M.A. (1998) Evaluation of Different Flax Varieties under Egyptian conditions. Proceedings Bast Fibrous Plants Today and Tomorrow, N. I. Vavilou Res. INS. Industry (VIR) St. Petersburg, Russia.

[11] El-Hariri, D.M, Hassanein, M.S. and El-Sweify, A.H. (2004) Evaluation of Same Flax Varieties, Straw Yield, Yield Components and Technological Characters. Agricultural Research, 75, 697-715.

[12] Peters, J.P. and Martinelli, J.A. (1989) Hierarchical Cluster Analysis as a Tool to Manage Variation in Germplasm Collections. Theoretical and Applied Genetics, 78, 42-48. http://dx.doi.org/10.1007/BF00299751

[13] Murphy, J.P., Cox, T.S. and Rodgers, D.M. (1986) Cluster Analysis of Red Winter Wheat Cultivars Based upon Coefficients of Parentage. Crop Science, 26, 672-676. http://dx.doi.org/10.2135/cropsci1986.0011183X002600040006x

[14] Chapman, H.D. and Pratt, P.F. (1978) Methods of Analysis for Soils, Plants and Water. Division of Agriclture Science, University of California, Berkley, 5-6.

[15] A.O.A.C. (1980) Official Methods of the Association of Official Analytical Chemists. 11th Edition, Association of Official Analytical Chemists, Washington DC.

[16] Snedecor, G.W. and Cochran, W.G. (1982) Statistical Method. 7th Edition, Iawa State University Press, Ames, 325330.

[17] Gomez, K. and Gomez, A.A. (1984) Statiscal Procedures for Agriculture Research. 2nd Edition, John Wiley and Sons, New York, 180.

[18] SAS Institute Inc. (2002) SAS Software v.9.1.3 sp4, Cary, NC: SAS Institute Inc.

[19] Ward Jr., J.H. (1963) Hierarchical Grouping to Optimize an Objective Function. Journal of the American Statistical Association, 58, 236-244. http://dx.doi.org/10.1080/01621459.1963.10500845

[20] Kineber, M.E.A., El-Emary, F.A. and El-Nady, M.F. (2006) Botanical Studies on Some Fibrous Flax (Linum usitatissmum L.) Genotypes Grown under Delta Conditions. Journal of Agricultural Science, 31, 2881-2890.

[21] El-Hariri, D.M., Bakry, A.B., Elewa, T.A. and Ibrahim, O.M. (2012) Evaluation of Some Flax (Linum usitatissimum L.) Varieties under Newly Reclaimed Sandy Soils Conditions. International Journal of Academic Research, 4, 98-102.

[22] Bakry, A.B., Nofal, O.A. and Zeidan, M.S. (2012) Agronomic Characteristics of Three Flax Varieties as Affected By Some Sources of Potassium Fertilization Under Newly Reclaimed Sandy Soil Conditions. Australian Journal of Basic and Applied Sciences, 6, 77-81.

[23] Verma, K.P. and Pathak, P.K. (1993) Response of Linseed (Linum usitatissmum L.) Varieties to Different Dates of Sowing. Indian Journal of Agronomy, 38, 160-163. 
[24] El-Nakhlawy, F.S. (1995) Studies on Seed Yield, Protein and Oil Contents and Fatty Acid Composition of Twenty Four Flax Varieties. Menofiya Journal of Agricultural Research, 20, 83-93.

[25] Dubey, M.P. (2001) Response of Late-Planted Linseed (Linum usitatissmum L.) Varieties to Nitrogen Levels under Rain Fed Conditions. Indian Journal of Agronomy, 46, 547-551.

[26] Kineber, M.E.A. and El-Sayed, A.S. (2004) Studies on Some Economic Characteristics in Flax (Linum usitatissmum L.) in North Delta Region of Egypt. Annals of Agricultural Sciences, 49, 71-81.

[27] El-Kady, E.A.F. and Abd El-Fatah, A.A.E. (2009) Comparison of Yield, Its Components Physical Properties and Chemical Composition of Twelve Flax Genotypes. Journal of Agricultural Research, 35, 69-85.

[28] Mohammedi, S.A. and Prasanna, B.M. (2003) Analysis of Genetic Diversity in Crop Plants—Salient Statistical Tools and Considerations. Crop Science, 43, 1235-1248. http://dx.doi.org/10.2135/cropsci2003.1235 
Scientific Research Publishing (SCIRP) is one of the largest Open Access journal publishers. It is currently publishing more than 200 open access, online, peer-reviewed journals covering a wide range of academic disciplines. SCIRP serves the worldwide academic communities and contributes to the progress and application of science with its publication.

Other selected journals from SCIRP are listed as below. Submit your manuscript to us via either submit@scirp.org or Online Submission Portal.
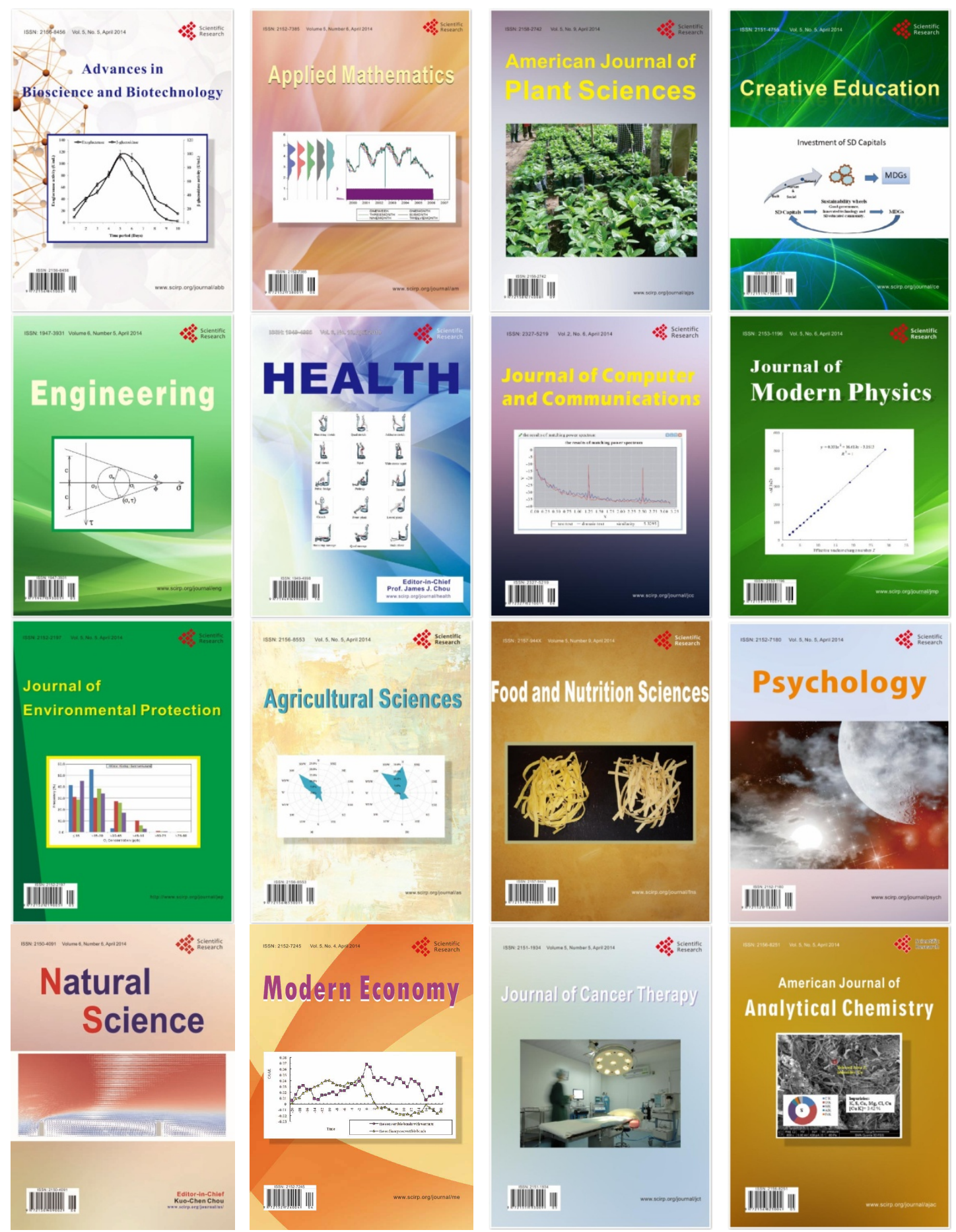